\title{
优化小学数学课堂教学, 提高小学数学质量
}

饶翠

南昌县东新乡中心小学

DOI:10.32629/jief.v2i5.1472

[摘 要] 小学数学是小学阶段一门十分重要的学科, 同时它也是学生在学习过程中遇到的一门有着一定难度的学科。为此如何在小学数学课 堂上改革课程教学, 提高课程教学质量也成为现代教师探索的一大难题。近些年来小学数学教学面临了一系列的改革, 它也使原有的课堂朝 着更好的方向发展。教师要积极顺应改革, 提升课堂教学效率。营造良好气氛, 开展游戏教学。从各方面提高小学数学课堂教学的实效性, 真正帮助学生完成数学思维的发展。

[关键词] 小学数学; 课堂教学; 教学质量

中图分类号: G633.6 文献标识码: A

由于长期应试教育的影响, 教师在讲课时往往趋向于一种单一的简 单授课模式。这给学生的数学思维带来了很大的局限性, 它是不利于学 生在数学课堂上完成学习效率提升的。为此教师也需要及时的改革课堂, 新时代的数学教师应该顺应目前的数学教学理念。在数学课堂内围绕数 学教学方法和数学教学手段开展教学, 优化小学数学课堂。了解学生学 习关键点, 以学生作为主体。知晓学生的思想动态, 让学生更好的在课 堂上获取知识, 积极参与到课堂学习过程中。

\section{1 做好备课, 提高数学课堂教学效率}

备课是展开数学教学的基础, 以往教师为了提高自我教学质量往往 会让学生在课下就做好预习工作。通过预习找出学生在学习过程中的关 键点, 这也是数学教学的一种有效措施。教师应该了解学生在学习过程 中的相关动态, 应用好数学教学方法在讲课过程中把重点突出来。让学 生了解教师讲解的重点之处, 将预先准备好的内容传递给生活化数学课 堂教学。这对于提高整个数学课堂教学质量来讲也是非常重要的, 在讲 解某个知识点时教师要着重把数学知识点进行分散。与整个数学书的知 识点串联起来, 建立完善的数学知识体系, 让学生在学习过程中了解知 识。

例如在教学《一元一次方程》这一相关知识点时, 在教学过程中教 师就应该先将一元一次方程的知识点进行列举, 串联未知数与变量之间 的相互关系。寻找各类知识点之间的共性, 最后对共性知识点进行总结。 这时在听课过程中学生也能够了解- - 原来每一个一元一次方程都含有 一个未知量, 而每个未知量的表达式也是不同的。它们可以用任意字母 来表达, 但是不管应用怎样的字母来表达, 其参数的含义都是相同的。 这些方程式在解答过程中也多使用同种方法, 教师应该抓住学生在数学 学习过程中的知识共同处。帮助学生对数学知识进行分类, 以此来展开 高效的备课内容。提高学生对于课堂学习的兴趣, 进一步完成课堂改革。

\section{2 营造数学气氛, 提升学生的课堂参与度}

好的环境是展开数学教学的基础, 为了让更多的学生自主投入到数 学学习过程中教师在创设教学活动时也要营造一个更为良好的数学学习 环境。以环境点亮学生的学习基础, 帮助学生改善学习方式。而在环境 构造方面, 教师也要着重构建一个宽松愉悦的课堂气氛。

引导学生进行深入, 教师要结合学生的具体发展特点以宽松氛围引 导学生参与学习。提高课堂教学质量, 而在创设教学氛围时教师也要了 解学生的具体需求。采用一定的教学方法, 取得优秀的教学成果。注重 学生的兴趣爱好, 以学生的兴趣作为前提吸引学生自主参与到课堂探究
过程中。利用一些现代化的多媒体工具提高学生参与度, 例如平常教师 就可以应用情景教学法在课堂内营造一个问题情景。让学生对数学学习 过程中的相关知识展开探究, 逐步引导学生通过探究思考解决问题。如 在教学《加减法》时, 教师就可以模拟超市购物情景让学生计算自己在 超市中到底花了多少钱。培养学生的合作学习意识, 让学生在良好的学 习氛围内探索数学知识。

\section{3 开创数学游戏, 激发学生学习兴趣}

游戏是小学阶段学生十分喜欢的一样东西, 在游戏过程中学生能够 全身心的放松自我。在数学课堂上教师也要活用游戏教学模式, 激发学 生对于数学学习的相关兴趣。利用游戏来满足学生的心理需求, 让学生 在数学课堂上了解游戏教学的相关魅力。这时学生在学习时也会更加投 入, 它对于提高整个数学课堂教学质量来讲是有着很大帮助的, 而在展 开数学游戏时, 教师可以采用的方法也有着很多。

例如平常教师在教学几何图形时就可以拿学生生活中常见的圆珠 笔、粉笔盒、黑板擦等立体图形, 让学生与课本上的图形进行对比。进 而了解各种图形的解决办法, 过后再依次挑选学生回答问题。对于回答 正确的学生, 教师要及时鼓励、增强学生的学习自信。而对于回答错误 的学生, 教师只要指出学生的错误点帮助学生了解错误、做出改正。这 样的游戏模式能够激发学生的学习兴趣, 必要时教师还可以采用知识竞 猜游戏来唤起班级成员的积极活跃度。它对于提高整个数学课堂教学质 量来讲是十分有效的, 教师应该用好游戏创设这样一种新型方法。

\section{4 总结}

小学数学课堂教学质量的提高需要教师对整个数学教学方式作出改 革, 教师应该以学生作为课堂教学的主体。从学生的角度、学生的视野 去制定教学目标, 了解优秀教学工作对于学生后期的指导作用。开放游 戏模式, 营造良好氛围。逐渐改变以往的传统教学模式, 应用高效游戏 模式来帮助学生深入课堂, 最终完成学生在课堂学习过程中的不断提高。

\section{[参考文献]}

[1]桑乃霞.小学数学教学中 “教学做合一” 的实践探究 [J]. 新课 程,2020(34):66.

[2]曾宪才. 试析小学数学的课堂教学 [N]. 科学导 报,2020-08-25(B03).

[3]陈再明. 有效构建小学数学互动课堂策略 [N]. 贵州民族 报,2020-08-27(B03). 